\title{
Mechanical Behavior and Microstructure Evolution of a Ti-15Mo/TiB Titanium-Matrix Composite during Hot Deformation
}

\author{
Sergey Zherebtsov ${ }^{1}{ }^{(0}$, Maxim Ozerov ${ }^{1, *}$, Margarita Klimova ${ }^{1}$, Dmitry Moskovskikh ${ }^{2}{ }^{(0)}$, \\ Nikita Stepanov ${ }^{1}$ (D) and Gennady Salishchev ${ }^{1}$ D \\ 1 Laboratory of Bulk Nanostructured Materials, Belgorod State University, Belgorod 308015, Russia; \\ zherebtsov@bsu.edu.ru (S.Z.); klimova_mv@bsu.edu.ru (M.K.); stepanov@bsu.edu.ru (N.S.); \\ salishchev@bsu.edu.ru (G.S.) \\ 2 Centre of Functional Nanoceramics, National University of Science and Technology, Moscow 119049, Russia; \\ mos@misis.ru \\ * Correspondence: ozerov@bsu.edu.ru; Tel.: +7-919-223-8528
}

Received: 26 September 2019; Accepted: 29 October 2019; Published: 31 October 2019

\begin{abstract}
A Ti-15Mo/TiB titanium-matrix composite (TMC) was produced by spark plasma sintering at $1400{ }^{\circ} \mathrm{C}$ under a load of $40 \mathrm{MPa}$ for 15 min using a Ti-14.25(wt.)\%Mo-5(wt.)\%TiB 2 powder mixture. Microstructure evolution and mechanical behavior of the composite were studied during uniaxial compression at room temperature and in a temperature range of $500-1000{ }^{\circ} \mathrm{C}$. At room temperature, the composite showed a combination of high strength (the yield strength was $1500 \mathrm{MPa}$ ) and good ductility ( $22 \%)$. The microstructure evolution of the Ti-15Mo matrix was associated with the development of dynamic recovery at $500-700{ }^{\circ} \mathrm{C}$ and dynamic recrystallization at higher temperatures $\left(\geq 800^{\circ} \mathrm{C}\right)$. The apparent activation energy of the plastic deformation was calculated and a processing map for the TMC was constructed using the obtained results.
\end{abstract}

Keywords: titanium-matrix composite; deformation; microstructure evolution; mechanical properties

\section{Introduction}

Due to a combination of high specific strength, excellent corrosion properties, and remarkable biocompatibility, titanium alloys are widely used in industry (e.g., shipbuilding, aircraft building, chemistry, food industry, etc.) and medicine (e.g., orthopedic and dental implants, surgery instruments) [1,2]. However, the absolute strength and hardness of titanium alloys are rather low and that limits their utilization for certain applications, especially in the case of most biocompatible pure titanium and some low-alloyed titanium alloys. A considerable increase in strength can be attained by complex alloying; however, the most accepted alloying elements (e.g., Al, V) can substantially deteriorate biocompatibility [3]. Searching for new titanium alloy compositions with satisfactory properties is still a challenging problem attracting a great deal of interest from materials scientists.

Another promising way to attain high strength and hardness without loss of biocompatibility and corrosion properties is associated with the production of titanium-based composites [4,5]. Among a variety of reinforcements, TiB seems to be the most suitable option due to very similar properties (density, thermal expansion coefficient, good crystallographic matching) with the Ti matrix $[5,6]$. Titanium-matrix composites (TMCs) can be produced using traditional metallurgical methods through the addition of B into melted Ti [6]. However, powder metallurgy is more preferable in order to obtain a finer microstructure. In this case, TiB reinforcements form in the Ti matrix during the in-situ $3 \mathrm{Ti}+\mathrm{TiB}_{2}=2 \mathrm{Ti}+2 \mathrm{TiB}$ reaction [6-8]. Due to high heating rate and high pressures, the spark plasma 
sintering (SPS) process can be used for powder consolidation at relatively low temperatures and for short time intervals, thereby preserving a very fine microstructure in the specimen [8]. Hard fibers of $\mathrm{TiB}$ increase the strength and hardness of TMC, however the ductility of the composite can decrease to nearly zero $[9,10]$.

Some improvement in both ductility and technological properties was attained in thermomechanically treated TMCs [11-17] due to the shortening and redistribution of TiB whiskers, along with the development of dynamic recrystallization in the titanium matrix. Another promising way to improve ductility of the composite can be associated with an increase in plasticity of the titanium matrix by adding a $\beta$-stabilizing element. In this case, a hard-to-deform hexagonal close-packed (hcp) lattice should become more ductile due to the greater number of slip systems in a body-centered cubic (bcc) lattice [1]. Meanwhile, there is a lack of information on both the mechanical properties of $\beta$-Ti-based TMCs and an influence of thermomechanical treatment on structure and properties of these materials.

In this work a bcc Ti-15 (wt.\%)Mo matrix (which is widely used for bio-medical applications) was reinforced by 8.5 vol.\% of TiB. This amount of TiB was selected using literature data for hcp Ti/TiB composites to attain a combination of high strength and satisfactory ductility [6]. It was selected to investigate the mechanical properties of the TBC at room temperature, to study the effect of hot deformation at $500-1000{ }^{\circ} \mathrm{C}$ and strain rates in the interval $5 \times 10^{-4}-10^{-2} \mathrm{~s}^{-1}$ on microstructure evolution and mechanical behavior. The obtained results will be used for the development of a proper thermomechanical treatment of the TMC.

\section{Materials and Procedure}

Powders of $\mathrm{Ti}$ ( $99.1 \%$ purity), Mo ( $99.95 \%$ purity), and $\mathrm{TiB}_{2}$ ( $99.9 \%$ purity) were used for the sintering of the Ti- $15 \mathrm{Mo} / \mathrm{TiB}$ composites with the bcc Ti matrix. The average sizes of the $\mathrm{Ti}, \mathrm{Mo}$, and $\mathrm{TiB}_{2}$ particles were 25, 3, and $4 \mu \mathrm{m}$, respectively (Figure 1). A mixture of the powders containing $80.75 \mathrm{wt} . \%$ $\mathrm{Ti}, 14.25 \mathrm{wt} . \%$ of Mo, and $5 \mathrm{wt} . \%$ of $\mathrm{TiB}_{2}$ (to obtain a Ti- $15 \mathrm{wt} . \%$ Mo alloy with 8.5 vol.\% of TiB) were produced using a Retsch RS200 vibrating cup mill (RETSCH, Haan, Germany) in ethanol at a milling rotation speed of $700 \mathrm{rpm}$. The mixing duration was $1 \mathrm{~h}$.

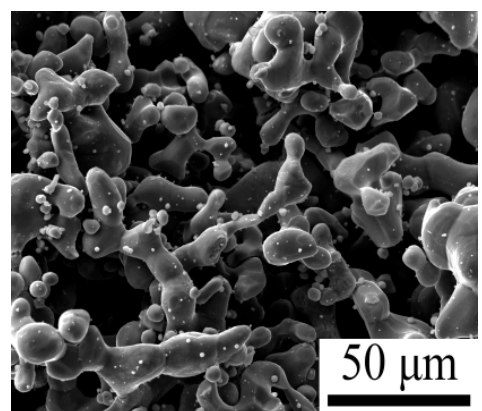

(a)

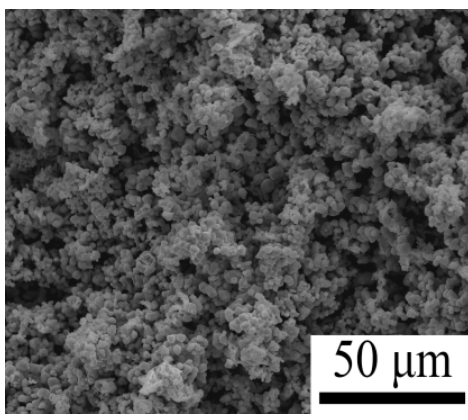

(b)

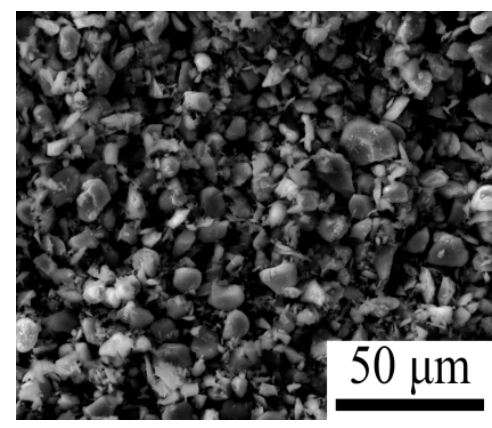

(c)

Figure 1. SEM images of (a) $\mathrm{Ti},(\mathbf{b}) \mathrm{Mo}$, and (c) $\mathrm{TiB}_{2}$ powders.

Cylindrical Ti-15Mo/TiB TMC specimens measured $15 \mathrm{~mm}$ in height and $19 \mathrm{~mm}$ in diameter and were produced using the SPS process under vacuum on a Thermal Technology SPS 10-3 machine (Thermal Technology, LLC, Santa Rosa, CA, USA) at $1400^{\circ} \mathrm{C}$ and $40 \mathrm{MPa}$ for $15 \mathrm{~min}$. Then, the sintered samples of the composite were homogenized at $1200^{\circ} \mathrm{C}$ for $24 \mathrm{~h}$ and cooled in air. To prevent oxidation during the homogenization annealing, the specimens were sealed in vacuumed quartz tubes filled with a titanium getter. The homogenized condition of the TMC is referred to as the initial one hereafter.

Specimens $\emptyset 7 \times 10 \mathrm{~mm}$ in high were cut from the homogenized composite using a Sodick AQ300L electro-discharge machine (Sodick Inc., Schaumburg, IL, USA). Then, the specimens were isothermally strained by compression in air at $20,500,600,700,800,900$, or $1000{ }^{\circ} \mathrm{C}$ on an Instron mechanical 
testing machine (INSTRON, Horwood, MA, USA). This was done at a nominal strain rate of $10^{-3} \mathrm{~s}^{-1}$ to $70 \%$ height reduction (a corresponding true strain was $\varepsilon \approx 1.2$ ) or to the specimens' fracture. The holding time at the required temperatures before the onset of deformation was $15 \mathrm{~min}$. After deformation, the specimens were air cooled. Strain-rate jump compressive tests were conducted at strain rates of $10^{-2}, 5 \times 10^{-3}, 10^{-3}$, and $5 \times 10^{-4} \mathrm{~s}^{-1}$ in the temperature interval $400-1000{ }^{\circ} \mathrm{C}$. The obtained data were used to determine the activation energy of deformation for the Ti-15Mo/TiB TMC.

Microstructure of the TMC in the initial condition and after deformation was studied using an FEI Quanta 600 FEG scanning electron microscope (Thermo Fisher Scientific, Hillsboro, OR, USA) and a JEOL JEM 2100 transmission electron microscope (JEOL, Tokyo, Japan). Mechanically polished specimens for SEM were etched with Kroll's reagent $\left(95 \% \mathrm{H}_{2} \mathrm{O}, 3 \% \mathrm{HNO}_{3}, 2 \% \mathrm{HF}\right)$. Samples for TEM analysis were prepared by twin-jet electro-polishing in a mixture of $60 \mathrm{~mL}$ perchloric acid, $600 \mathrm{~mL}$ methanol, and $360 \mathrm{~mL}$ butanol at $-35^{\circ} \mathrm{C}$ and $29 \mathrm{~V}$. The spacing between the TiB whiskers was evaluated based on seven TEM images (more than 100 measurements in total) using the linear-intercept method. Phase composition of the TMC was evaluated using X-ray diffraction (XRD) on an ARL-Xtra diffractometer (Thermo Fisher Scientific, Portland, OR, USA) with $\mathrm{Cu} \mathrm{K} \alpha$ radiation. The volume fraction of the phases was determined using the Rietveld method [18].

To determine the optimal processing window, a processing map was constructed using the obtained results for a true strain of 1.2. Toward this end, power dissipation efficiency $(\eta)$ was evaluated in comparison with an ideal linear dissipator (i.e., with $m=1): \eta=2 m /(m+1)$ [19], with the strain rate sensitivity of flow stress $m=\frac{\Delta \log \sigma}{\Delta \log \dot{\varepsilon}}$ (here $\sigma$ and $\dot{\varepsilon}$ are the flow stress and strain rate, respectively). The processing map shows a three-dimensional area projection describing the $\eta$ isolines, depending on the strain rate and temperature on the $T-\dot{\varepsilon}$ surface.

\section{Results}

Microstructure of the Ti-15Mo/TiB composite in the initial condition (i.e., after the homogenization annealing at $1200^{\circ} \mathrm{C}$ for $24 \mathrm{~h}$ ) consisted of the $\beta$-Ti matrix reinforced by TiB whiskers (Figure 2a-c). Due to rather high sintering and/or homogenization temperatures, the cross-section of some TiB whiskers attained $\sim 3-4 \mu \mathrm{m}$ (Figure $2 \mathrm{~b}$,c). Nevertheless, the average diameter was almost an order of magnitude smaller ( $200 \mathrm{~nm})$. Dislocation density in the titanium matrix was higher nearby or between the TiB whiskers (Figure 2d). Grain boundaries in the titanium matrix were not detected on TEM images and the spacing between the TiB whiskers (which can be accepted in a first approximation as a free dislocation path) was $\sim 0.5-0.7 \mu \mathrm{m}$.

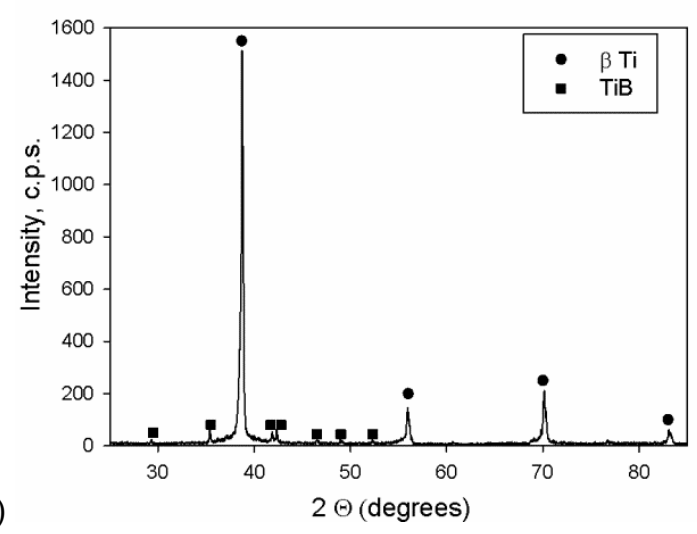

(b)

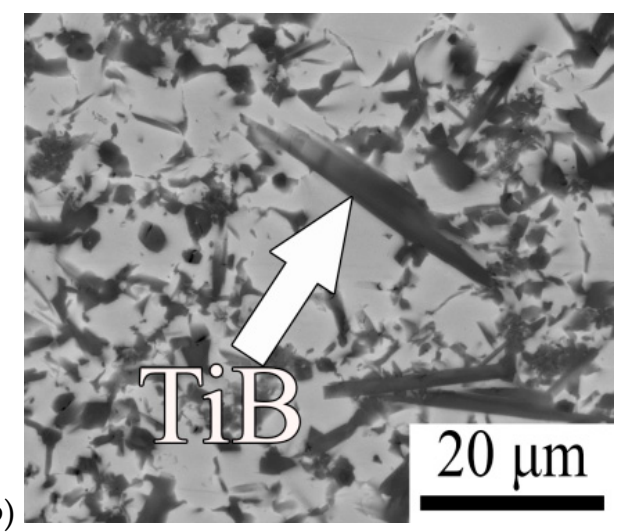

Figure 2. Cont. 
(c)
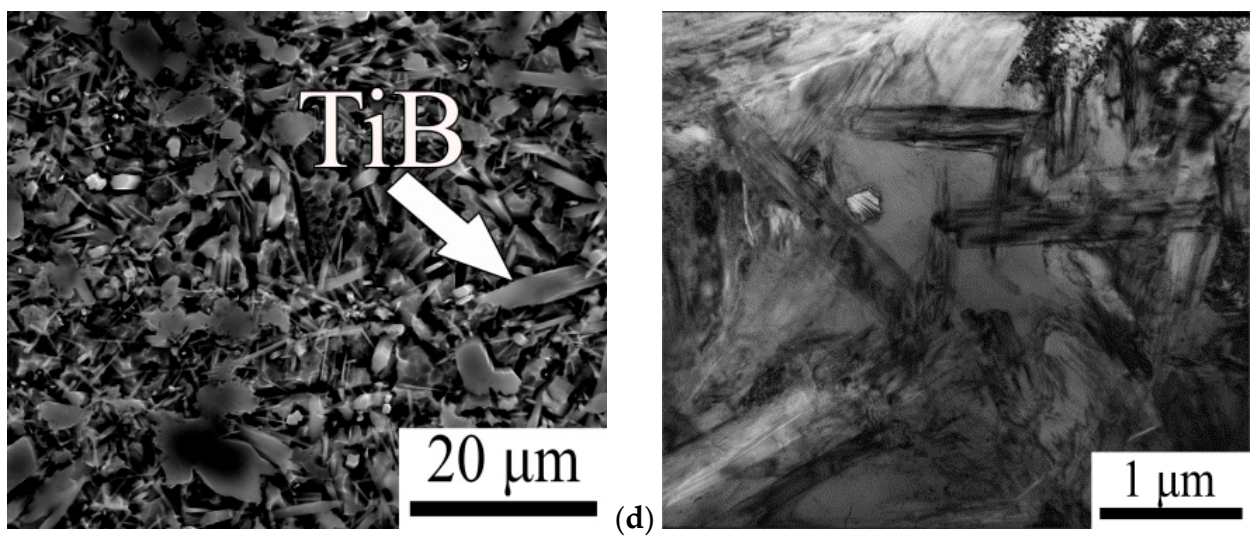

Figure 2. Microstructure of the Ti-15Mo/TiB titanium-matrix composite (TMC) in the initial condition: (a) XRD pattern, (b) SEM image of unetched surface; (c) SEM image of etched surface; (d) TEM bright field image.

During compression at room temperature, the composite showed an attractive combination of strength (the yield strength was $\sim 1480 \mathrm{MPa}$ and the ultimate strength was almost $2 \mathrm{GPa}$ ) and ductility ( 22\% height reduction) (Figure $3 a)$. A short plateau just before the fracture can most likely be associated with strain localization.
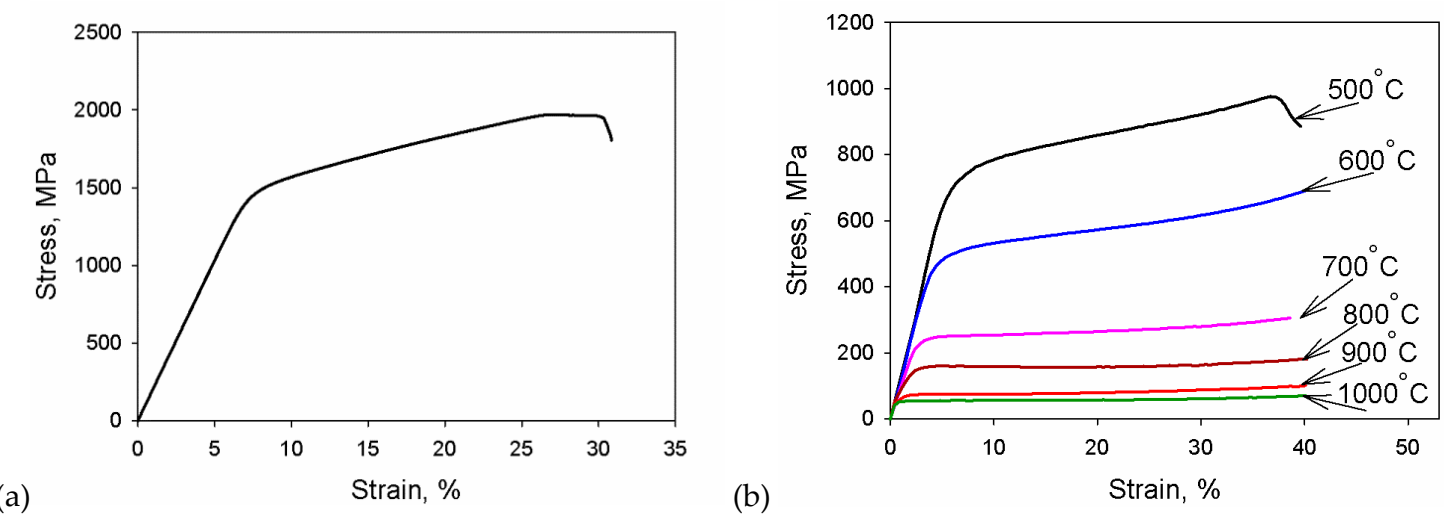

Figure 3. Flow curves obtained during compression at (a) $20^{\circ} \mathrm{C}$ or at (b) $500-1000^{\circ} \mathrm{C}$ of the Ti- $15 \mathrm{Mo} / \mathrm{TiB}$ TMC at a nominal strain rate $10^{-3} \mathrm{~s}^{-1}$.

Deformation of the Ti-15Mo/TiB TMC in compression resulted-after initial hardening transient-in continuous strengthening at $500-700^{\circ} \mathrm{C}$ (this interval is below the $\alpha+\beta \leftrightarrow \beta$ transition, which occurs at $727^{\circ} \mathrm{C}$ for the Ti-15Mo alloy [20]) or steady-state flow at higher temperatures, that is, at $800-1000{ }^{\circ} \mathrm{C}$ (Figure $3 b$ ). The latter can be ascribed to dynamic recrystallization/recovery processes typical of hot deformation. The yield strength gradually decreased from $630 \mathrm{MPa}$ at $500{ }^{\circ} \mathrm{C}$ to $45 \mathrm{MPa}$ at $1000^{\circ} \mathrm{C}$. At $500{ }^{\circ} \mathrm{C}$, the TMC fractured at $\sim 30 \%$ reduction.

The microstructure evolution during deformation was associated with some shortening of TiB whiskers (from $\sim 6 \mu \mathrm{m}$ in the initial condition to $\sim 3.5 \mu \mathrm{m}$ in all specimens deformed at $500-1000{ }^{\circ} \mathrm{C}$ ) and their preferred orientation along the metal flow direction (shown by arrows in Figure 4). The redistribution process appeared to be more pronounced with an increase in temperature.

XRD analysis indicated the formation of the $\alpha$ phase in the $\beta$ matrix during deformation. The volume fraction of the $\alpha$ phase was found to be $\sim 17 \%-22 \%$ in the interval $500-800{ }^{\circ} \mathrm{C}$ (this interval corresponds to the minimal stability of the $\beta$ phase [21]) and decreased to $\sim 7 \%$ while increasing in deformation temperature to $1000{ }^{\circ} \mathrm{C}$ (Figure 5). The volume fraction of TiB was found to be $\sim 9 \%$ in the whole temperature interval. 
(a)

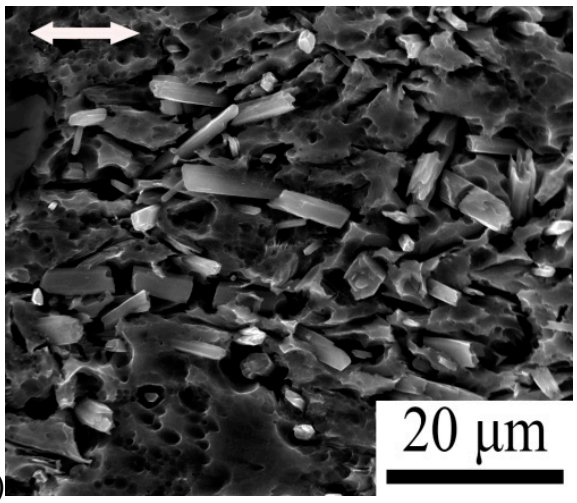

(b)
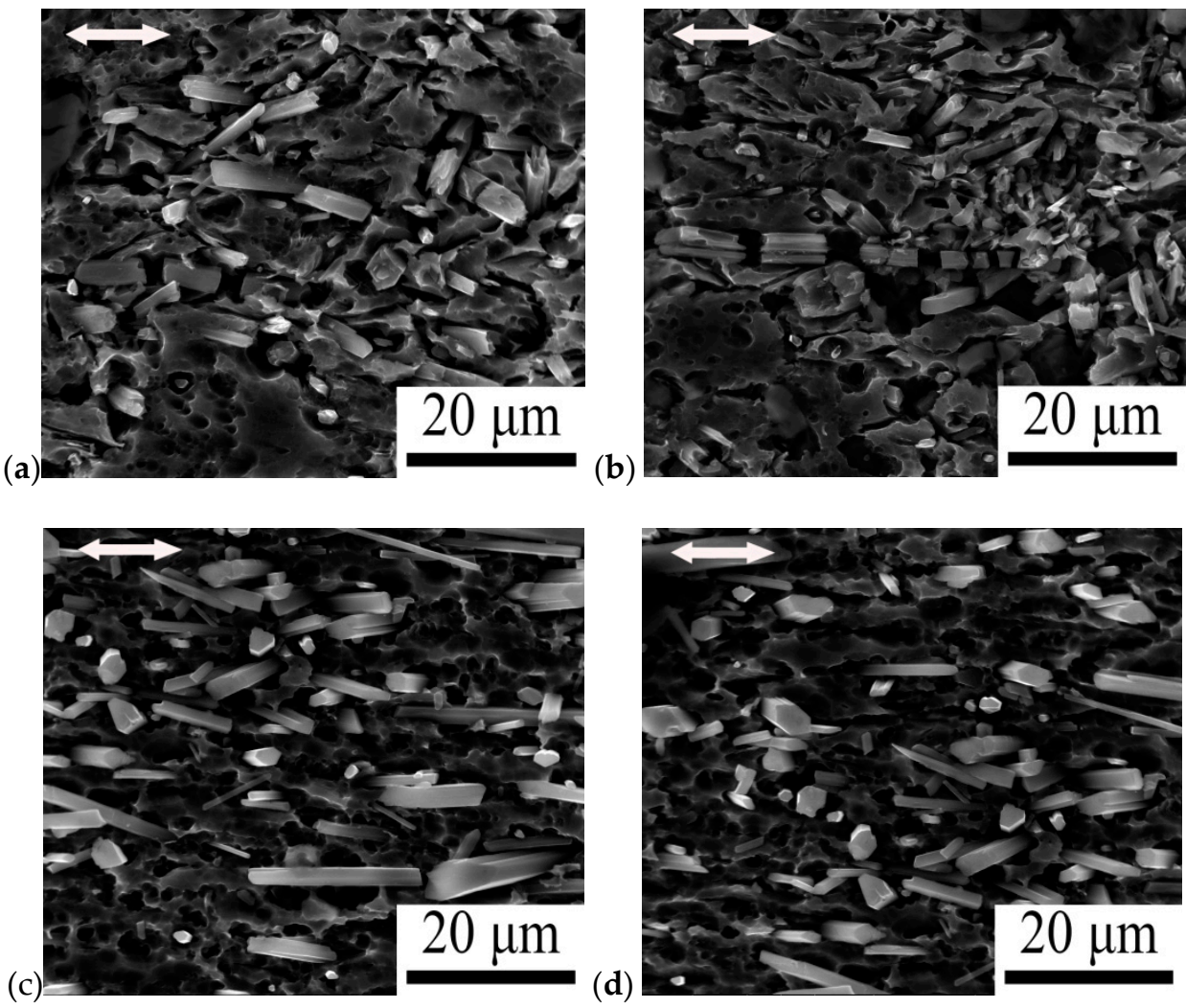

(d)
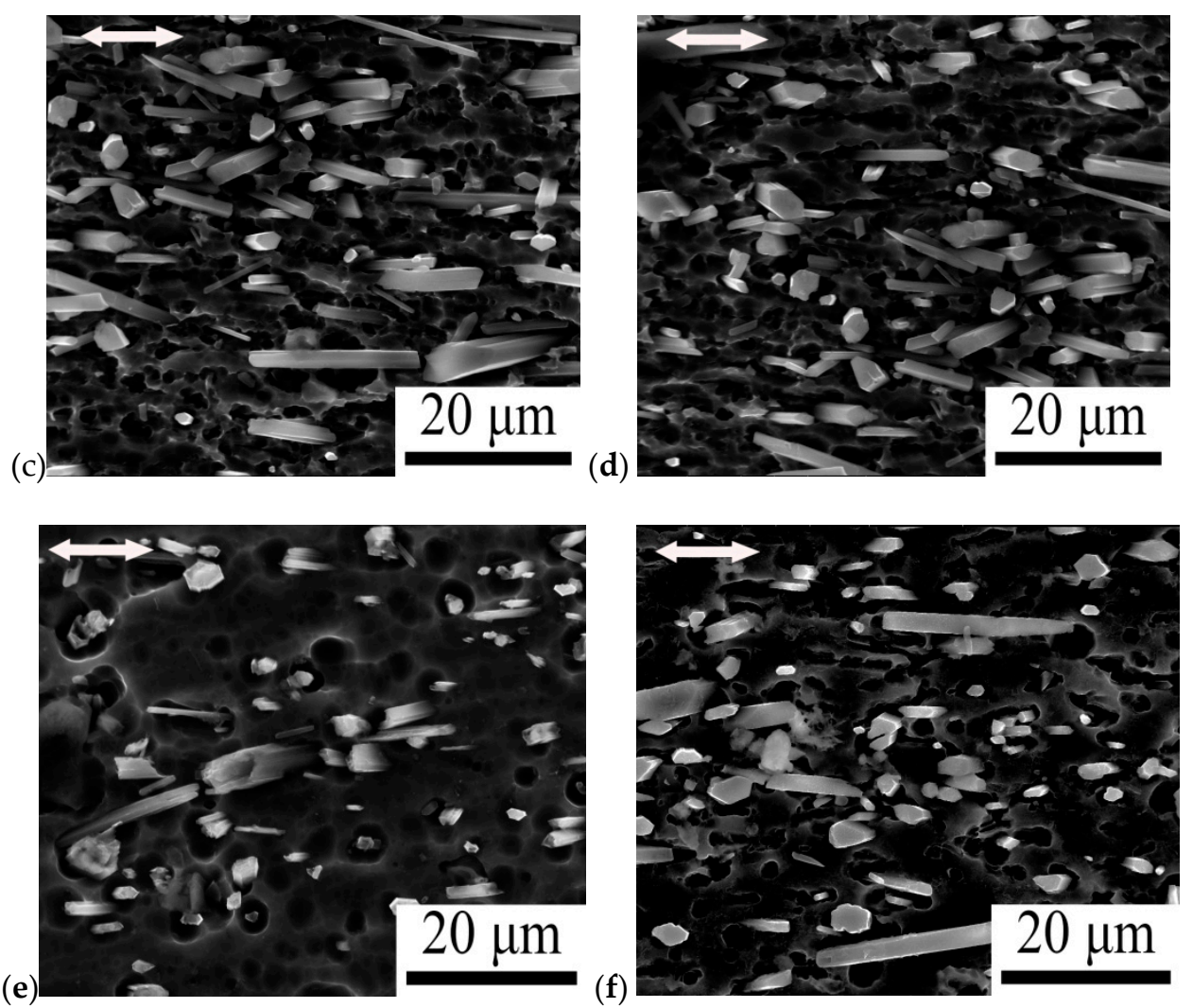

Figure 4. SEM microstructure of the Ti-15Mo/TiB TMC produced using spark plasma sintering (SPS) at $1400{ }^{\circ} \mathrm{C}$; uniaxial compression at a nominal strain rate of $10^{-3} \mathrm{~s}^{-1}$ and temperatures (a) $500{ }^{\circ} \mathrm{C}$, (b) $600{ }^{\circ} \mathrm{C}$, (c) $700{ }^{\circ} \mathrm{C}$, (d) $800{ }^{\circ} \mathrm{C}$, (e) $900{ }^{\circ} \mathrm{C}$, and (f) $1000{ }^{\circ} \mathrm{C}$. The compression axis is vertical in all cases and the metal flow direction is shown by arrows.

The TEM investigation showed the formation of a typical deformed microstructure with a rather high dislocation density and dislocation cells/pile-ups after deformation at low temperatures $\left(500-600{ }^{\circ} \mathrm{C}\right)$ (Figure 6a,b). However, areas with a decreased dislocation density were already observed at $600{ }^{\circ} \mathrm{C}$ (Figure 6b). In addition, lens-shaped $\alpha$-phase lamellae (up to $0.1 \mu \mathrm{m}$ width) were found (Figure 6b). An increase in deformation temperature resulted in the development of dynamic recrystallization, associated with an overall decrease in dislocation density, formation of new recrystallized grains, and straightening of grain boundaries (Figure $6 \mathrm{c}, \mathrm{d}$ ). The size of the recrystallized grains increased with temperature from $\sim 1 \mu \mathrm{m}$ at $800{ }^{\circ} \mathrm{C}$ (Figure $6 \mathrm{c}$ ) to $2-3 \mu \mathrm{m}$ at $1000{ }^{\circ} \mathrm{C}$ (Figure $6 \mathrm{~d}$ ). At all temperatures, the $\mathrm{Ti} / \mathrm{TiB}$ interfaces were quite clean and did not contain any cracks or pores. 


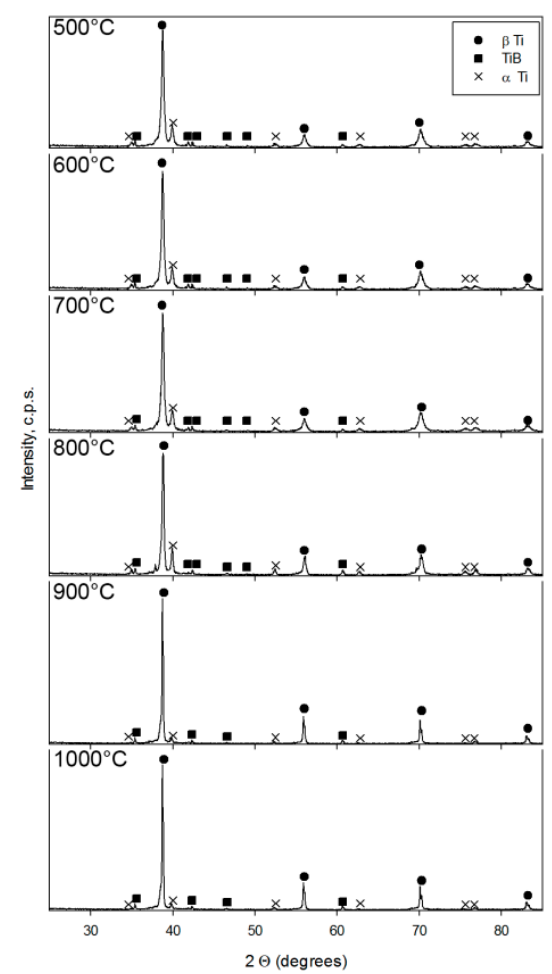

Figure 5. XRD patterns of the Ti-15Mo/TiB MMC after compression at different temperatures.
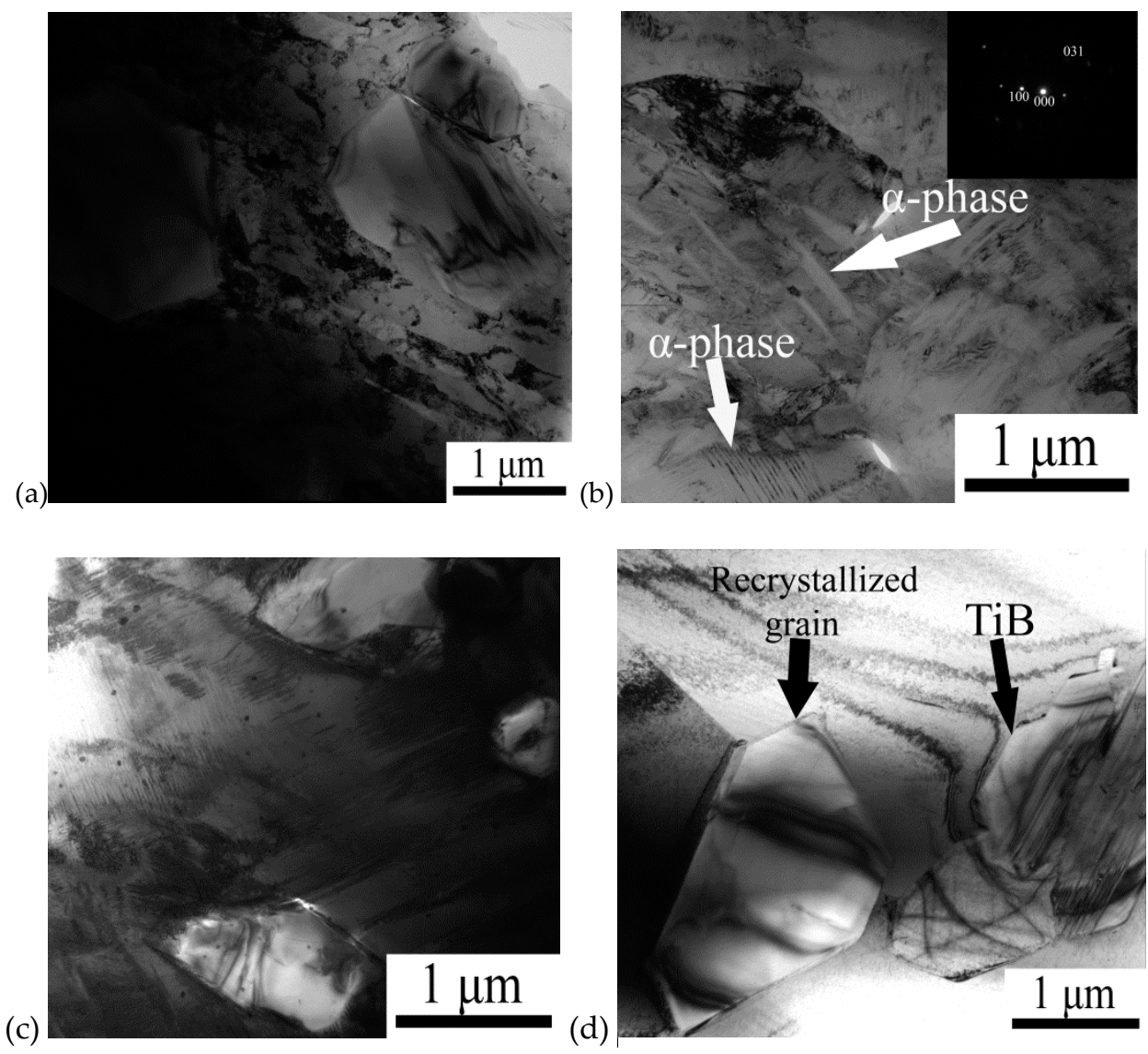

Figure 6. TEM microstructure of the Ti-15Mo/TiB TMC after uniaxial compression at $(\mathbf{a}, \mathbf{b}) 600{ }^{\circ} \mathrm{C}$, (c) $800{ }^{\circ} \mathrm{C}$ and (d) $1000{ }^{\circ} \mathrm{C}$. Selected area diffraction pattern for the $\alpha$-phase is inserted in (b). 


\section{Discussion}

The obtained results demonstrate a definite beneficial effect of the matrix transition from the hcp alpha titanium to the bcc beta titanium. The latter was obtained through the addition of $15 \mathrm{wt} . \%$ of Mo into Ti. The composite produced by SPS showed a very attractive combination of strength and ductility (1.5-2 GPa and $\sim 22 \%$, respectively) (Figure 3a) at room temperature, which is superior to most of the $\beta$-rich alloys in the heat-strengthened condition [22] or metal-matrix composites with the hcp $\alpha$-Ti matrix $[4,23,24]$. The observed increase in ductility is obviously associated with a greater number of slip systems in the bcc lattice in comparison with that of the hcp one [25]. Lower compression ductility of the hcp Ti/TiB (4\%-17\%, depending on sintering methods) was also reported in $[23,24]$. The very high strength of the Ti- $15 \mathrm{Mo} / \mathrm{TiB}$ composite can be ascribed to the superposition of several strengthening mechanisms with Orowan strengthening providing the main contribution [26,27]. Some additional strengthening effects in comparison with the hcp Ti/TiB composites [28] is most likely the result of solid solution strengthening.

An increase in testing temperature led to a decrease in both yield and flow stresses and an improvement in ductility (Figure $3 b$ ) due to the activation of additional deformation mechanisms. For example, the pronounced softening at $\mathrm{T} \geq 700^{\circ} \mathrm{C}$ can be associated with the development of dynamic recrystallization (Figure $6 c, d$ ). Meanwhile, precipitations of the $\alpha$-phase particles (Figures 5 and $6 b$ ) should result in some increase in the overall strength. Deformation-induced precipitation of the $\alpha$-phase particles could be the reason for the hardening transient at the stress-strain curves obtained at $500-700{ }^{\circ} \mathrm{C}$ (Figure $3 \mathrm{~b}$ ). Note that the $\alpha$ phase was found in the composite after compression in the full temperature range of $500-1000^{\circ} \mathrm{C}$ (Figure 5). However, the $\alpha$ phase formation at temperatures above the $\alpha+\beta \leftrightarrow \beta$ transition $\left(727^{\circ} \mathrm{C}\right.$ for the Ti-15Mo alloy [18]) obviously occurred during cooling from the deformation temperatures. That is why the fraction of the $\alpha$ phase was lower after deformation at the high temperatures.

Since some improvement in mechanical properties can be attained in the composites through hot/warm working [14,29], the obtained results on mechanical behavior during hot deformation were used to determine the optimal processing window. The temperature-strain rate map in Figure 7 shows domains where deformation capacity of the composite was high enough for hot/warm working (i.e., areas associated, for example, with superplasticity or dynamic recrystallization). The map also predicts domains of unstable plastic flow where deformation of the composite can be associated with early necking and/or crack formation [30]. The maximum values of dissipation are expectably related to the highest temperature and the lowest strain rate (the bottom-right corner in Figure 7). However, even at relatively low temperatures $\left(700-800^{\circ} \mathrm{C}\right)$ and strain rates $5 \times 10^{-4}-10^{-3} \mathrm{~s}^{-1}$ the value of $\eta$ fell in the interval $0.35-04$, thereby suggesting sufficiently favorable hot working conditions. The obtained results (Figure 7) suggest the occurrence of dynamic recrystallization/recovery in these domains, warranting satisfactory deformability. At higher temperatures, good ductility of the composite was accompanied by intensive grain growth, which is not advantageous for the performance properties.

To gain insight into the operative deformation mechanisms, the apparent activation energy of plastic deformation was calculated using the obtained results (Figure 8). The calculated values of the apparent activation energy were found to be $Q=241 \mathrm{~kJ} / \mathrm{mol}$ for the high-temperature interval (700-1000 ${ }^{\circ} \mathrm{C}$ ) with $n \approx 5$ and $Q=135 \mathrm{~kJ} / \mathrm{mol}$ with $n=10$ for lower temperatures. The former value of $Q$ is very similar to that observed in [20] for the Ti/TiB composite with the hcp $\alpha$-Ti matrix during deformation in the $\beta$ phase field region (i.e., at temperatures above $900{ }^{\circ} \mathrm{C}$ ), where $Q$ was found to be $250 \mathrm{~kJ} / \mathrm{mol}$. This value being higher than that reported for self-diffusion in $\beta$ titanium (153 kJ/mol) [31] can be ascribed to dislocation slip inhibition due to the presence of the TiB whiskers [32]. In addition, similar values of $Q=250-330 \mathrm{~kJ} / \mathrm{mol}$ were reported in [33] for glide along the prism planes with the thermally activated overcoming of solute atoms as the main rate-controlling mechanism. An increase in the value of $Q$ can also be related to the occurrence of discontinuous dynamic recrystallization during hot deformation [34]. 


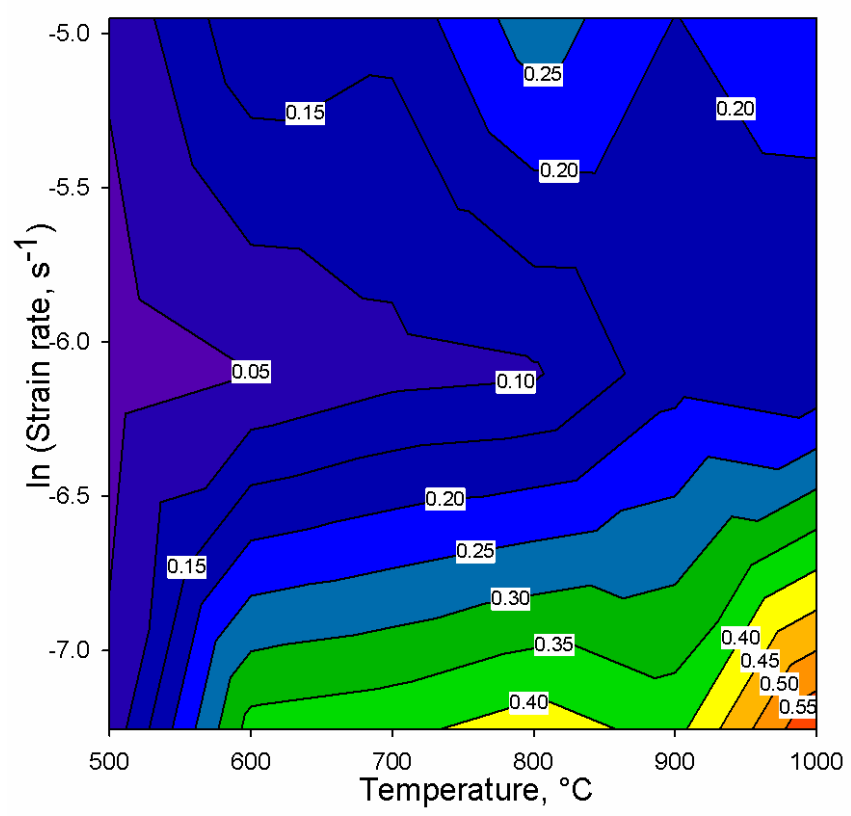

Figure 7. Processing map for the Ti-15Mo/TiB composite.
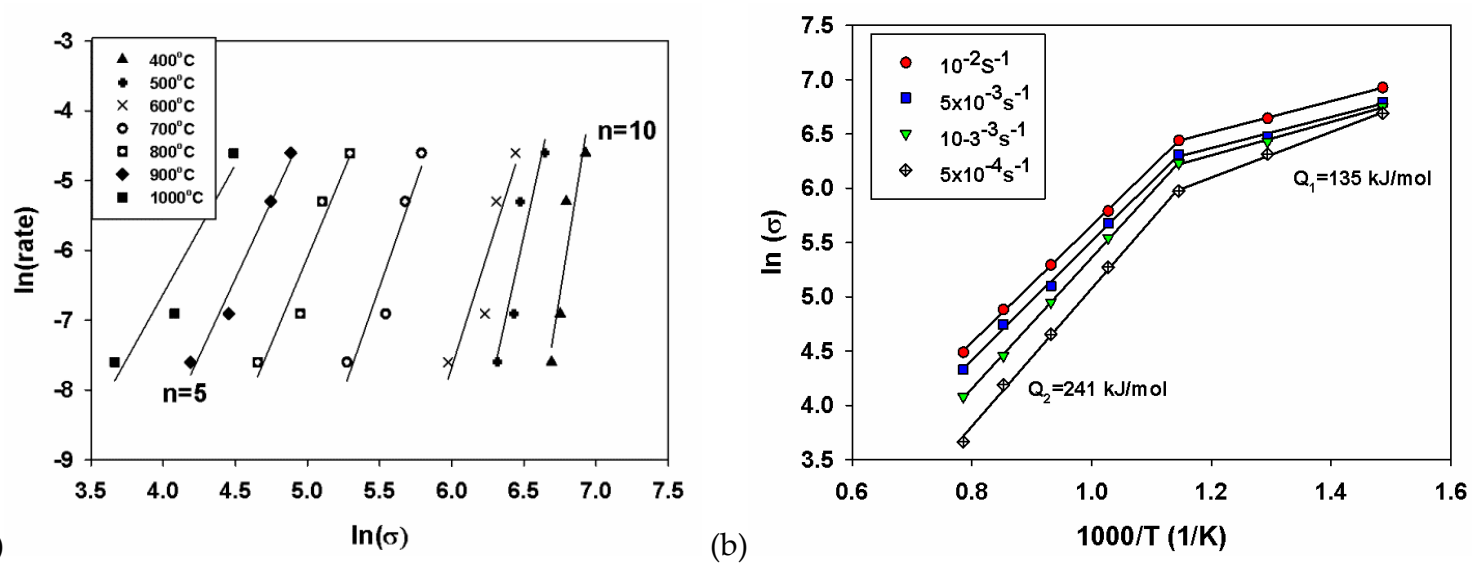

Figure 8. (a) Log-log dependence of strain rate on stress and (b) Arrhenius semi-log plot of steady-state flow stress vs. inversed temperature for the Ti-15Mo/TiB TMC strained in the interval $T=400-1000{ }^{\circ} \mathrm{C}$.

In the lower temperature range $\left(400-600^{\circ} \mathrm{C}\right)$ the value of $Q=135 \mathrm{~kJ} / \mathrm{mol}$ suggests that deformation is controlled by volume or pipe diffusion $[31,35]$ associated with the development of dynamic recovery or continuous dynamic recrystallization. Microstructural observations confirmed the development of dynamic recovery in the TMC during compression at $600{ }^{\circ} \mathrm{C}$ (Figure $6 \mathrm{~b}$ ).

Quite low values of strain rate sensitivity $m=1 / n \approx 0.1-0.2$ (Figure 8 a) along the obtained values of activation energy suggest the operation of dislocation-related mechanisms, mainly (dislocation glide/climb) during deformation in the studied temperature interval $[33,36]$.

\section{Summary}

In this work, the structure and compression mechanical behavior of a Ti-15Mo/TiB titanium-matrix composite (TMC) produced by spark plasma sintering were studied. The following conclusions were drawn:

(1) The Ti-15Mo/TiB TMC fabricated by spark plasma sintering at $1400{ }^{\circ} \mathrm{C}$ under a load of $40 \mathrm{MPa}$ for 15 min using a Ti-14.25(wt.)\%Mo- 5 (wt.)\%TiB 2 powder mixture was composed of $\beta$-Ti matrix reinforced with TiB whiskers with the average diameter of $200 \mathrm{~nm}$. The as-sintered TMC had 
attractive compression mechanical properties at room temperature: yield strength $1480 \mathrm{MPa}$ and ductility $\sim 22 \%$.

(2) The uniaxial compression in the temperature range of $500-1000^{\circ} \mathrm{C}$ demonstrated gradual softening with an increase in deformation temperature. Microstructure evolution of the Ti-15Mo matrix was associated with the development of dynamic recovery at $500-700^{\circ} \mathrm{C}$ and dynamic recrystallization at temperatures $\geq 800^{\circ} \mathrm{C}$. Reorientation of TiB whiskers toward the metal flow direction and some shortening of the whiskers also occurred. In addition, the precipitation of the $\alpha$ particles was found after deformation at $500-1000{ }^{\circ} \mathrm{C}$.

(3) The optimal parameters of thermomechanical processing for the Ti-15Mo/TiB TMC were associated with deformation temperatures of $700-800^{\circ} \mathrm{C}$ and strain rates of $5 \times 10^{-4}-10^{-3} \mathrm{~s}^{-1}$.

Author Contributions: S.Z. conceived and designed the experiments. M.O. performed the experiments. D.M. prepared the TEM specimens. M.K. carried out microstructure analysis. S.Z., N.S., M.O., and G.S. analyzed the data and wrote the paper.

Funding: This research was funded by Russian Science Foundation, grant number 15-19-00165.

Acknowledgments: The authors gratefully acknowledge the financial support from the Russian Science Foundation (Grant Number 15-19-00165). The authors are grateful to the personnel of the Joint Research Centre at Belgorod State University for their assistance with the instrumental analysis.

Conflicts of Interest: The authors declare no conflict of interest.

\section{References}

1. Leyens, C.; Peters, M. Titanium and Titanium Alloys: Fundamentals and Applications; Wiley-VCH: Weinheim, Germany, 2003; pp. 1-499.

2. Khorasani, A.M.; Goldberg, M.; Doeven, E.H.; Littlefair, G. Titanium in biomedical applications-Properties and fabrication: A review. J. Biomater. Tissue Eng. 2015, 5, 593-619. [CrossRef]

3. Chen, Q.; Thouas, G.A. Metallic implant biomaterials. Mater. Sci. Eng. R Rep. 2015, 87, 1-57. [CrossRef]

4. Saito, T.; Furuta, T.; Yamaguchi, T. Development of low cost titanium matrix composite. In Advances in Titanium Metal Matrix Composites, the Minerals, Metals and Materials Society; Froes, F.H., Storer, J., Eds.; TMS: Warrendale, PA, USA, 1995; pp. 33-44.

5. Godfrey, T.M.T.; Goodwin, P.S.; Ward-Close, C.M. Titanium Particulate Metal Matrix Composites-Reinforcement, Production Methods, and Mechanical Properties. Adv. Eng. Mater. 2000, 2, 85-91. [CrossRef]

6. Morsi, K.; Patel, V.V. Processing and properties of titanium-titanium boride (TiBw) matrix composites-A review. J. Mater. Sci. 2007, 42, 2037-2047. [CrossRef]

7. Ravi Chandran, K.S.; Panda, K.B.; Sahay, S.S. TiBw-reinforced Ti composites: Processing, properties, application, prospects, and research needs. JOM 2004, 56, 42-48. [CrossRef]

8. Feng, H.; Zhou, Y.; Jia, D.; Meng, Q.; Rao, J. Growth mechanism of in situ TiB whiskers in spark plasma sintered TiB/Ti metal matrix composites. Cryst. Growth Des. 2006, 6, 1626-1630. [CrossRef]

9. Ozerov, M.; Stepanov, N.; Kolesnikov, A.; Sokolovsky, V.; Zherebtsov, S. Brittle-to-ductile transition in a Ti-TiB metal-matrix composite. Mater. Lett. 2017, 187, 28-31. [CrossRef]

10. Ozerov, M.; Klimova, M.; Vyazmin, A.; Stepanov, N.; Zherebtsov, S. Orientation relationship in a Ti/TiB metal-matrix composite. Mater. Lett. 2017, 186, 168-170. [CrossRef]

11. Gaisin, R.A.; Imayev, V.M.; Imayev, R.M. Effect of hot forging on microstructure and mechanical properties of near $\alpha$ titanium alloy/TiB composites produced by casting. J. Alloys Compd. 2017, 723, 385-394. [CrossRef]

12. Ozerov, M.S.; Gazizova, M.Y.; Klimova, M.V.; Stepanov, N.D.; Zherebtsov, S.V. Effect of Plastic Deformation on the Structure and Properties of the Ti/TiB Composite Produced by Spark Plasma Sintering. Russ. Metall. (Met.) 2018, 7, 638-644. [CrossRef]

13. Zherebtsov, S.; Ozerov, M.; Stepanov, N.; Klimova, M.; Ivanisenko, Y. Effect of high-pressure torsion on structure and microhardness of Ti/TiB metal-matrix composite. Metals 2017, 7, 507. [CrossRef]

14. Ozerov, M.; Klimova, M.; Sokolovsky, V.; Stepanov, N.; Popov, A.; Boldin, M.; Zherebtsov, S. Evolution of microstructure and mechanical properties of Ti/TiB metal-matrix composite during isothermal multiaxial forging. J. Alloys Compd. 2019, 770, 840-848. [CrossRef] 
15. Imayev, V.; Gaisin, R.; Gaisina, E.; Imayev, R.; Fecht, H.-J.; Pyczak, F. Effect of hot forging on microstructure and tensile properties of Ti-TiB. Mater. Sci. Eng. A 2014, 609, 34-41. [CrossRef]

16. Ozerov, M.S.; Klimova, M.V.; Stepanov, N.D.; Zherebtsov, S.V. Microstructure evolution of a Ti/TiB metal-matrix composite during high-temperature deformation. Mater. Phys. Mech. 2018, 38, 54-63. [CrossRef]

17. Zherebtsov, S.; Ozerov, M.; Stepanov, N.; Klimova, M. Structure and properties of Ti/TiB metal-matrix composite after isothermal multiaxial forging. Acta Phys. Pol. A 2018, 134, 695-698. [CrossRef]

18. Will, G. Powder Diffraction: The Rietveld Method and the Two-Stage Method to Determine and Refine Crystal Structures from Powder Diffraction Data; Springer: Berlin, Germany, 2005.

19. Prasad, Y.V.R.K.; Rao, K.P.; Sasidhara, S. Hot Working Guide: A Compendium of Processing Maps; ASM International: Materials Park, OH, USA, 2015; pp. 1-625.

20. Weiss, I.; Semiatin, S.L. Thermomechanical processing of beta titanium alloys-An overview. Mater. Sci. Eng. A 1998, 243, 46-65. [CrossRef]

21. Jiang, B.; Tsuchiya, K.; Emura, S.; Min, X. Effect of high-pressure torsion process on precipitation behavior of $\alpha$ phase in $\beta$-type Ti-15Mo alloy. Mater. Trans. 2014, 55, 877-884. [CrossRef]

22. Ilyin, A.A.; Kolachev, B.A.; Polkin, I.S. Titanium Alloys. Composition, Structure, Properties; VILS-MATI Publishing: Moscow, Russia, 2009.

23. Jeong, H.W.; Kim, S.J.; Hyun, Y.T.; Lee, Y.T. Densification and Compressive Strength of In-situ Processed Ti/TiB Composites by Powder Metallurgy. Metals Mater. Int. 2002, 8, 25-35. [CrossRef]

24. Attar, H.; Bönisch, M.; Calin, M.; Zhang, L.-C.; Scudino, S.; Eckert, J. Selective laser melting of in situ titanium-titanium boride composites: Processing, microstructure and mechanical properties. Acta Mater. 2014, 76, 13-22. [CrossRef]

25. Meyers, M.A.; Chawla, K.K. Mechanical Behavior of Materials; Cambridge University Press: New York, NY, USA, 2009.

26. Casati, R.; Vedani, M. Metal Matrix Composites Reinforced by Nano-Particles-A review. Metals 2004, 4, 65-83. [CrossRef]

27. Zherebtsov, S.; Ozerov, M.; Klimova, M.; Stepanov, N.; Vershinina, T.; Ivanisenko, Y.; Salishchev, G. Effect of High-Pressure Torsion on Structure and Properties of Ti-15Mo/TiB Metal-Matrix Composite. Materials 2018, 11, 2426. [CrossRef] [PubMed]

28. Morsi, K. Review: Titanium-titanium boride composites. J. Mater. Sci. 2019, 54, 6753-6771. [CrossRef]

29. Ozerov, M.; Klimova, M.; Kolesnikov, A.; Stepanov, N.; Zherebtsov, S. Deformation behavior and microstructure evolution of a Ti/TiB metal-matrix composite during high-temperature compression tests. Mater. Des. 2016, 112, 17-26. [CrossRef]

30. Rao, K.P.; Prasad, Y.V.R.K. Advanced Techniques to Evaluate Hot Workability of Materials. Compr. Mater. Process. 2014, 3, 397-426. [CrossRef]

31. Frost, H.J.; Ashby, M.F. Deformation-Mechanism Maps; Pergamon Press: Oxford, UK, 1982; pp. 1-166.

32. Zhang, Y.; Huang, L.; Liu, B.; Geng, L. Hot deformation behavior of in-situ TiBw/Ti6Al4V composite with novel network reinforcement distribution, Trans. Nonferrous Metals Soc. 2012, 22, 465-471. [CrossRef]

33. Conrad, H. Effect of interstitial solutes on the strength and ductility of titanium. Prog. Mater. Sci. 1981, 26, 123-403. [CrossRef]

34. Raj, S.V.; Langdon, T.G. Creep behavior of copper at intermediate temperatures-I. Mechanical characteristics. Acta Metall. 1989, 37, 843-852. [CrossRef]

35. Walsöe De Reca, N.E.; Libanati, C.M. Autodifusion de titanio beta y hafnio beta. Acta Metall. 1968, 16, 1297-1305. [CrossRef]

36. Kumari, S.; Prasad, N.E.; Chandran, K.S.R.; Malakondaiah, G. High-temperature deformation behavior of Ti-TiBw in-situ metal-matrix composites. JOM 2004, 56, 51-55. [CrossRef]

(C) 2019 by the authors. Licensee MDPI, Basel, Switzerland. This article is an open access article distributed under the terms and conditions of the Creative Commons Attribution (CC BY) license (http://creativecommons.org/licenses/by/4.0/). 